\title{
UN ECOSOC 고위급 회의 개발협력포럼(DCF)
}

2010년도 UN ECOSOC 고위급회의(2010년 6월 28일 7월 2일) 주요 일정으로 6월 29일 30일간 개 발협력포럼(Development Cooperation Forum: DCF)이 개최되어 개발을 위한 정책일관성을 비롯한 국 제개발협력 관련 주요 사안에 대해 아래와 같은 내용으로 포괄적인 토의를 하였음.

\section{I. 회의개요}

○ 개최 일시 : 2010년 6월 29일 6월 30일

○ 개최 목적 및 주제

(1) 개최 목적

공여국, 수원국, 의회, 시민사회, global funds등의 개발협력 이해관계자들이 개발협력 주 요 의제를 논의함으로써, 2010년 9월 'MDGs 고위급회의' 및 2011년 제4차 원조효과 고위 급회의(HLF-4)에 기여

(2) 주제

개발을 위한 정책일관성 및 기타 국제개발협력 관련 주요 사안

\section{II. 요지}

1. 천년개발목표(이하 $\mathrm{MDGs}$ ) 달성을 위한 로드맵 마련의 필요성

2. 승수효과를 가져오는 여성-여아에 대한 투자 및 개도국 국내재원 조달 역량 강화에 대한 지원 필요성

3. 금년 9월 'MDGs Summit'에서 2011년 2015년간 MDGs 달성 가속화를 위해 공여 주체들이 ambitious targets를 수립할 것을 강력히 권고

4. 공여국-수원국이 공동으로 개발을 위한 정책일관성(이하 $\mathrm{PCD})$ 을 심층 분석하여 이른바 "beyondaid 이슈 간의 일관성 확보 필요성 강조 
5. 원조효과성 제고를 위해서는 수원국 및 non-executive stakeholders가 역량개발 및 상호책임 성 관련 이슈에 적극 개입해야 함.

6. 남남협력의 이익을 충분히 활용해야 함.

\section{III. 관찰 및 평가}

1. 국가간 견해차에도 불구하고 대다수 국가가 정책일관성(이하 $\mathrm{PCD}$ )의 필요성에 대해 공감하고 있으므로 향후 $\mathrm{PCD}$ 에 대한 논의가 더욱 구체화 될 것으로 예상됨.

2. $\mathrm{PCD}$ 달성을 위한 제도적 장치를 갖춘 선진사례를 분석할 필요성을 노정

3. 대다수 개도국은 $\mathrm{OECD} / \mathrm{DAC}$ 중심으로 이루어지고 있는 원조효과성 논의의 정당성과 투명성에 이의를 제기하고 있으므로 제4차 원조효과고위급회의(이하 $\mathrm{HLF}-4$ )에서는 보다 다양한 개발협 력 이해관계자의 참여가 필요

4. $\mathrm{HLF}-4$ 개최국인 한국은, 보편적 참여가 확보된 $\mathrm{DCF}$ 에서 남남협력의 성과 및 작업계획을 설명 하는 side event를 개최하여 지지의 제고 기회로 활용한 남남협력 태스크팀(TT-SSC)의 예를 홍보전략에 참고할 수 있을 것으로 보임. 